\title{
A Climatic Driver for Abrupt Mid-Holocene Vegetation Dynamics and the Hemlock Decline in New England
}

\section{Citation}

Foster, D. R., Oswald, W. W. , Faison, E. K. , Doughty, E. D. , Hansen, B. C. S. 2006. A climatic driver for abrupt mid-Holocene vegetation dynamics and the hemlock decline in New England. Ecology 87: 2959-2966.

\section{Published Version}

10.1890/0012-9658(2006)87[2959:ACDFAM]2.0.C0;2

\section{Permanent link}

http://nrs.harvard.edu/urn-3:HUL.InstRepos:30676636

\section{Terms of Use}

This article was downloaded from Harvard University's DASH repository, and is made available under the terms and conditions applicable to Other Posted Material, as set forth at http:// nrs.harvard.edu/urn-3:HUL.InstRepos:dash.current.terms-of-use\#LAA

\section{Share Your Story}

The Harvard community has made this article openly available.

Please share how this access benefits you. Submit a story.

\section{Accessibility}




\title{
A CLIMATIC DRIVER FOR ABRUPT MID-HOLOCENE VEGETATION DYNAMICS AND THE HEMLOCK DECLINE IN NEW ENGLAND
}

\author{
David R. Foster, ${ }^{1,3}$ W. Wyatt Oswald, ${ }^{1}$ Edward K. Faison, ${ }^{1}$ Elaine D. Doughty, ${ }^{1}$ and Barbara C. S. Hansen ${ }^{2}$ \\ ${ }^{1}$ Harvard Forest, Harvard University, 324 North Main Street, Petersham, Massachusetts 01366 USA \\ ${ }^{2}$ Limnological Research Center, University of Minnesota, Minneapolis, Minnesota 55455 USA
}

\begin{abstract}
The mid-Holocene decline of eastern hemlock is widely viewed as the sole prehistorical example of an insect- or pathogen-mediated collapse of a North American tree species and has been extensively studied for insights into pest-host dynamics and the consequences to terrestrial and aquatic ecosystems of dominant-species removal. We report paleoecological evidence implicating climate as a major driver of this episode. Data drawn from sites across a gradient in hemlock abundance from dominant to absent demonstrate: a synchronous, dramatic decline in a contrasting taxon (oak); changes in lake sediments and aquatic taxa indicating low water levels; and one or more intervals of intense drought at regional to continental scales. These results, which accord well with emerging climate reconstructions, challenge the interpretation of a biotically driven hemlock decline and highlight the potential for climate change to generate major, abrupt dynamics in forest ecosystems.
\end{abstract}

Key words: climate change; forest dynamics; hemlock decline; Holocene; New England (USA); oak decline; paleoecology; pollen record.

\section{INTRODUCTION}

Understanding the dynamics and controls of broadscale outbreaks of pests and pathogens in forest ecosystems is of fundamental and practical importance due to their profound impacts on ecosystem structure and function, and consequences for biodiversity and regional economies (e.g., Anderson et al. 2004). One extensively studied paleoecological benchmark for such biotic impacts is the abrupt decline of eastern hemlock (Tsuga canadensis) $\sim 5500$ years ago, which is portrayed as the sole example of a prehistorical pest or pathogen outbreak in North America, and one of the most important examples of temperate forest dynamics since deglaciation (Webb 1982, Allison et al. 1986, Foster and Zebryk 1993, Fuller 1998, Bennett and Fuller 2002). Historically interpreted as driven by climate change (Deevey 1939), the hemlock decline was first attributed to a pest or pathogen by M. B. Davis (1981). Davis' and subsequent interpretations (e.g., Allison et al. 1986, Davis 1989) are based on the observation that the decline appeared to be (a) species specific, (b) range wide (Webb 1982, Bennett and Fuller 2002), (c) synchronous (currently dated at $4750{ }^{14} \mathrm{C}$ yr $=5500$ calendar years

Manuscript received 15 February 2006; revised 6 June 2006; accepted 5 July 2006. Corresponding Editor: C. C. Labandeira.

${ }^{3}$ E-mail: drfoster@fas.harvard.edu before present) (Bennett and Fuller 2002), and (d) abrupt, with a palynological signature analogous to the historical chestnut blight (Cryphonectria parasitica), which eliminated American chestnut (Castanea dentata) as an overstory tree in eastern North America (Allison et al. 1986). The suggestion by Davis (1981) that an insect like the eastern hemlock looper (Lambdina fiscellaria) may have been responsible for this dynamic gained support when fossil remains of the looper and chewed hemlock needles were located in sediments exhibiting a pollen record of the decline (Anderson et al. 1986, Bhiry and Filion 1996). Alternatively, many entomologists suggest that the signature and duration of the hemlock decline is inconsistent with that of known insect impacts and more analogous to a fungal or viral pathogen (J. Elkinton, personal communication). This pathogenic interpretation has also been favored by other paleoecological studies (Allison et al. 1986, Davis 1989).

Over the years numerous researchers examining longterm vegetation and climate dynamics have questioned Davis' interpretation that biotic factors were the major driver of the hemlock decline and have suggested that the proximal factor may be broad-scale climatic change. Recently, considerable paleoclimatic evidence has emerged indicating that the decline coincided with a dry climatic interval that induced regional-to-continental changes in vegetation and water levels $(\mathrm{Yu}$ and 
TABLE 1. Sites in southern New England, USA, mentioned in the text.

\begin{tabular}{|c|c|c|c|c|}
\hline Site & $\begin{array}{l}\text { N latitude } \\
\left({ }^{\circ}\right)\end{array}$ & W longitude & $\begin{array}{l}\text { Elevation } \\
(\mathrm{m})\end{array}$ & Reference \\
\hline \multicolumn{5}{|l|}{ Study sites } \\
\hline Berry Pond East & 42.620 & -71.087 & 43 & Oswald et al. (in press) \\
\hline Berry Pond West & 42.505 & -73.319 & 631 & Whitehead (1979) \\
\hline Black Gum Swamp & 42.536 & -72.214 & 358 & Foster and Zebryk (1993) \\
\hline Blaney's Pond & 41.467 & -70.767 & 15 & W. W. Oswald and D. R. Foster (unpublished data) \\
\hline Blood Pond & 42.080 & -71.962 & 214 & Oswald et al. (in press) \\
\hline Cedar Tree Neck Bog & 41.428 & -70.700 & 20 & Stevens $(1996)$ \\
\hline Deep Pond & 41.581 & -71.640 & 23 & W. W. Oswald and D. R. Foster (unpublished data) \\
\hline Duck Pond & 41.933 & -70.001 & 3 & Winkler (1985) \\
\hline Fresh Pond & 41.161 & -71.579 & 28 & Dunwiddie (1990) \\
\hline Hawley Bog & 42.575 & -72.890 & 549 & W. A. Patterson (unpublished data) \\
\hline Little Pond & 42.675 & -72.192 & 302 & Oswald et al. (in press) \\
\hline Mohawk Pond & 41.817 & -73.283 & 360 & Gaudreau (1986) \\
\hline No Bottom Pond & 41.285 & -70.114 & 8 & Dunwiddie (1990) \\
\hline North Pond & 42.651 & -73.054 & 586 & Whitehead and Crisman (1978) \\
\hline Rogers Lake & 41.367 & -72.117 & 91 & Davis (1969) \\
\hline Wildwood Lake & 40.892 & -72.673 & 5 & W. W. Oswald and D. R. Foster (unpublished data) \\
\hline Winneconnet Pond & 41.971 & -71.133 & 22 & Suter $(1985)$ \\
\hline \multicolumn{5}{|l|}{ Other sites } \\
\hline Crooked Pond & 41.892 & -70.650 & 28 & Shuman et al. (2001) \\
\hline Makepeace Cedar Swamp & 41.933 & -70.766 & 40 & Newby et al. (2000) \\
\hline Owl Pond & 41.770 & -70.016 & 7 & Tzedakis (1992) \\
\hline
\end{tabular}

McAndrews 1994, Yu et al. 1997, Haas and McAndrews 2000, Shuman et al. 2001, 2004, 2005b, Calcote 2003). These findings, coupled with evidence that mid-Holocene climate fluctuations may be linked to changes in solar activity (Magny and Haas 2004, Magny et al. 2006), raise again the potential of an important role for environmental change in this striking forest dynamic.

Identification of the factors controlling the hemlock decline and recovery has importance because many studies have drawn far-reaching ecological and evolutionary interpretations based on the assumption that the decline is a model system for the reduction of a single species independent of environmental drivers (Fuller 1998, Foster 2000). These interpretations bear on such fundamental processes as: (a) forest succession and ecological resilience (Fuller 1998, St. Jacques et al. 2000), (b) terrestrial-aquatic ecosystem coupling and the relationship between ecosystem nutrient retention and biomass dynamics (Hall and Smol 1993, St. Jacques et al. 2000), (c) synergies between natural disturbances (e.g., pest outbreaks and fire) (Foster and Zebryk 1993), (d) equilibrium of the vegetation-climate system (Fuller 1998, Shuman et al. 2004), and (e) the evolutionary biology of pest-host systems (Davis 1981, 1989).

\section{Methods}

To interpret the mid-Holocene environmental and ecological dynamics surrounding the hemlock decline, we investigated changes in forest composition and sediment characteristics between 8000 and 2000 calendar years before present at 17 sites across southern New England (USA) and compared these to regional and global climatic reconstructions (Table 1, Fig. 1). The sites span a biophysical gradient from the higherelevation inland region of Massachusetts, with cool, moist climate and a relatively short growing season, to lower-elevation coastal areas of New York, Rhode Island, and Massachusetts, which are characterized by warmer, drier climate and a three-week-longer growing season (Foster and Aber 2004). Modern vegetation ranges from northern hardwood-hemlock-white pine (Pinus strobus) forest on shallow till soils inland to a complex of vegetation on deep glacial deposits in the coastal region of Cape Cod and adjacent islands (Foster and Aber 2004). Near the coast, finer-textured soils support oak (Quercus spp.) with some beech (Fagus grandifolia) and maple (Acer spp.), whereas pitch pine (Pinus rigida) and scrub oak (Quercus ilicifolia) predominate on coarse-grained outwash soils. This regional environmental gradient also appears to have controlled patterns of vegetation during the Early Holocene, when hemlock was abundant in the northwestern portion of the study area but rare or absent along the coast (Fig. 1).

Pollen and chronological data were obtained from the North American Pollen Database (available online) $)^{4}$ and Harvard Forest studies. Radiocarbon dates were converted to calendar years before present (cal. yr BP) using OxCal 3.9 (Bronk Ramsey 2001) and age-depth models were constructed by linear interpolation between selected dates. We examined the timing, rate, magnitude, and compositional direction of vegetation changes across this relatively small region $(500 \times 200 \mathrm{~km})$, and compared these dynamics with local, regional, and global records of past environmental variability. By examining changes across the regional gradient, we sought to disentangle the relative impact of hemlock dynamics vs. environmental changes on overall forest dynamics.

\footnotetext{
${ }^{4}$ 〈www.ncdc.noaa.gov/paleo/napd.html〉
} 

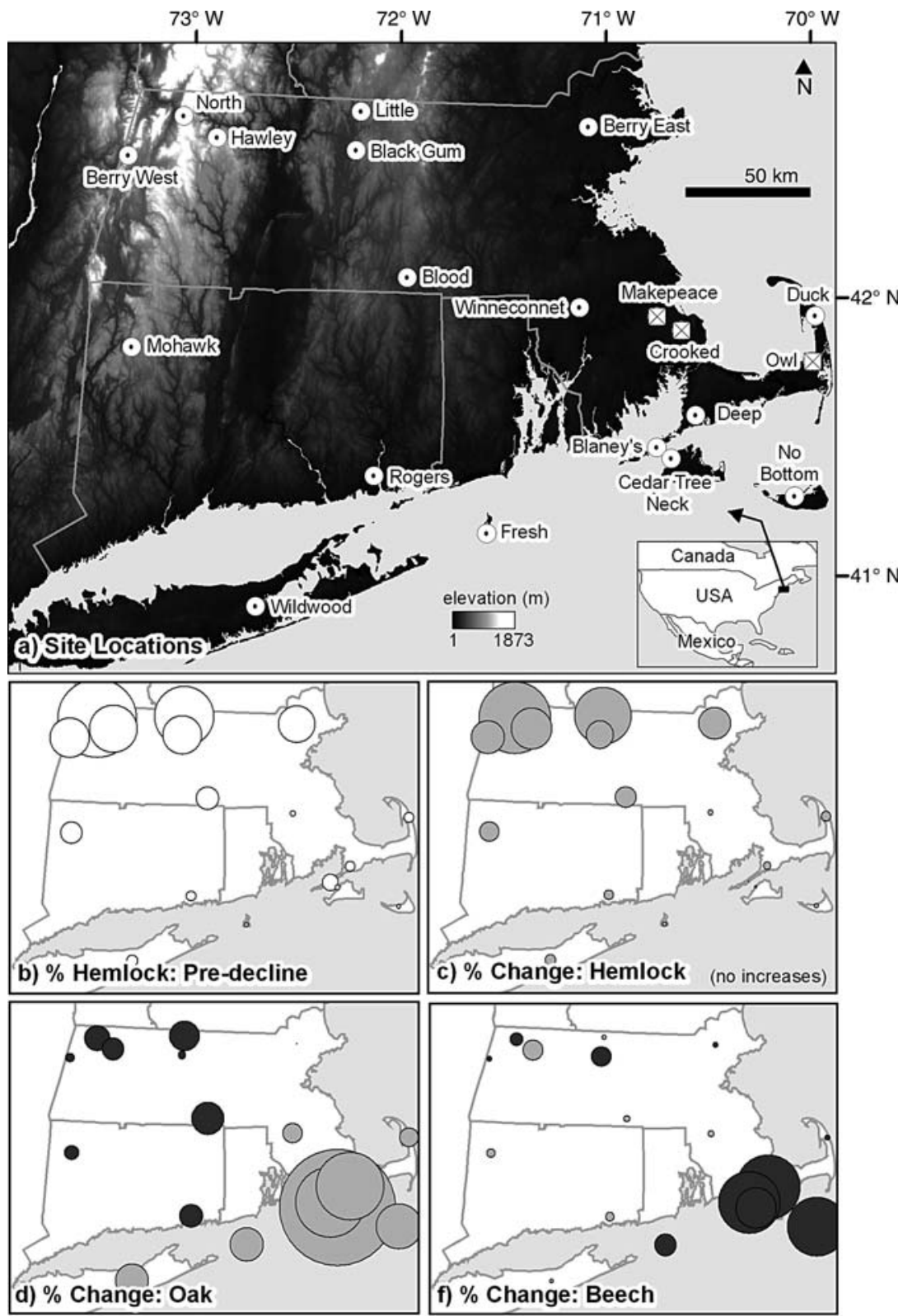

c) \% Change: Hemlock (no increases)

\section{b) \% Hemlock:Pre-decline}
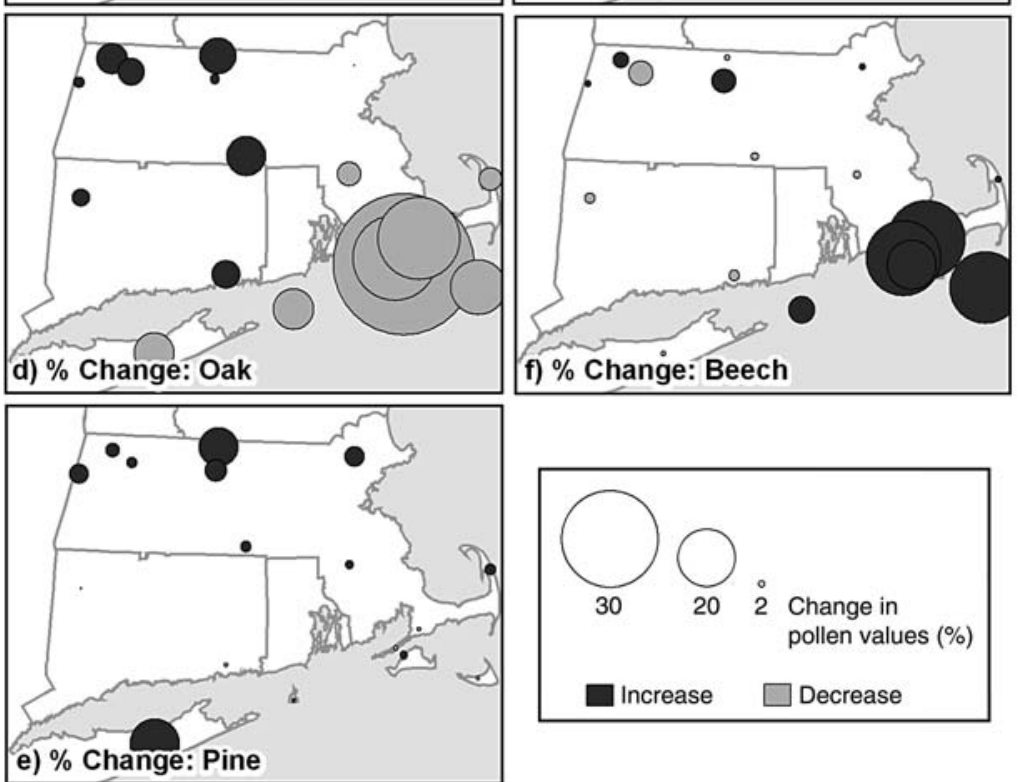

FIG. 1. (a) Map of study sites (circles) and other cited locations (squares; Tzedakis 1992, Newby et al. 2000, Shuman et al. 2001) in southern New England, USA. (b) Percentage pollen values for hemlock for samples immediately before the hemlock decline. Hemlock pollen abundance varied from $>30 \%$ at inland sites to $0-5 \%$ on the coast. (c-f) Change in pollen percentage values for various taxa during the hemlock decline, calculated as the difference between the sample immediately before the decline (average age $\pm \mathrm{SD}=5490 \pm 190 \mathrm{yr}$ ) and the sample where hemlock abundance is lowest (4260 $\pm 510 \mathrm{yr}$ ). Regression of pre-decline hemlock percentage vs. the percentage change at the decline yields $r^{2}=0.99$. 

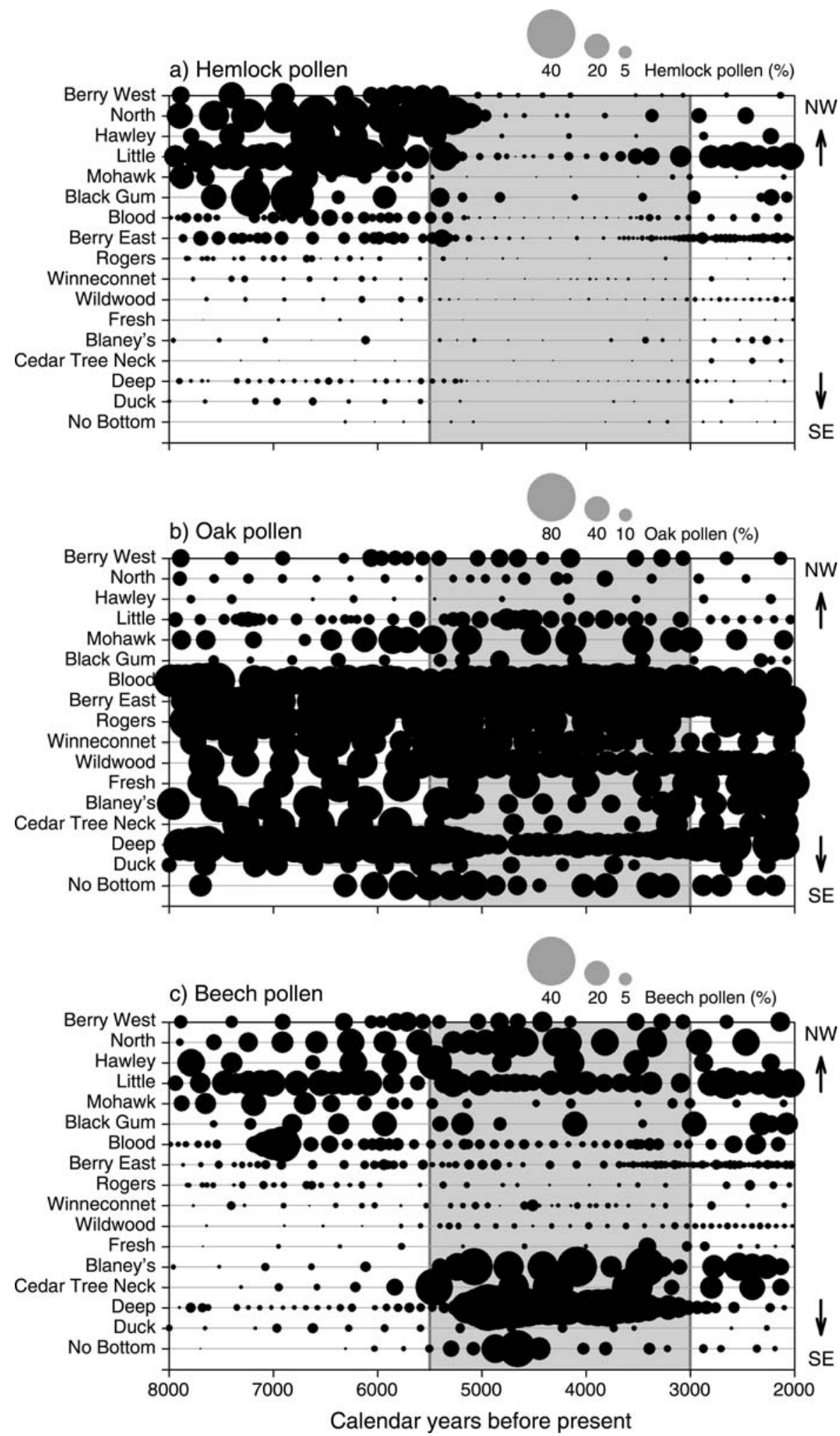

FIG. 2. Pollen data from 17 study sites in southern New England (for site locations see Fig. 1): (a) hemlock pollen percentage values, illustrating the mid-Holocene interval of low hemlock abundance in the northwestern portion of the study area; (b) oak pollen percentage values, showing the mid-Holocene decline of oak at several coastal sites; and (c) beech pollen percentage values, with elevated abundance at several coastal sites during the mid-Holocene interval. Shading delineates the interval of dry climate between 5500 and 3000 cal. yr BP. 

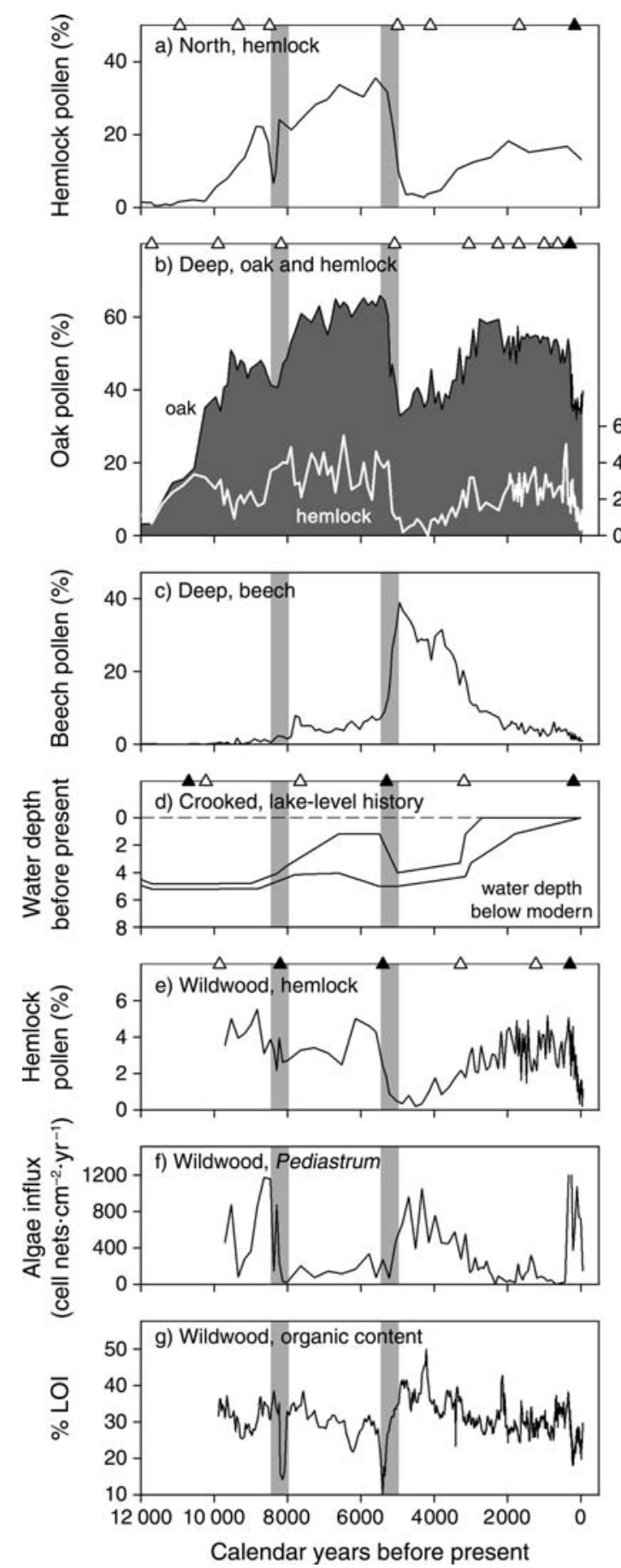

FIG. 3. Paleoenvironmental data from key sites across southern New England (Fig. 1) for 12000 cal. yr BP to the present. (a) Hemlock pollen percentage for North Pond, exhibiting low values at ca. $8200 \mathrm{cal}$. yr $\mathrm{BP}$ and during the mid-Holocene interval. (b) Oak and hemlock pollen percentage for Deep Pond; note the similarity between the stratigraphic patterns of oak at Deep Pond and hemlock at North Pond. (c) Beech pollen percentage for Deep Pond, featuring the interval of high abundance between ca. 5500 and 3000 cal. yr BP. (d) Reconstruction of past variations in water depth (meters below modern) for Crooked Pond (Shuman et al. 2001); note the interval of low lake level coincident with the mid-Holocene

\section{RESUlts}

The period 5500-3000 cal. yr BP is characterized by geographically consistent changes in vegetation across southern New England, USA (Figs. 1 and 2). The hemlock decline is (a) abrupt at all sites, (b) proportional to its pre-decline abundance, and (c) apparently synchronous and chronologically consistent with other studies (Bennett and Fuller 2002). At inland sites, where the hemlock decline is most striking, there are corresponding increases in the abundance of oak and pine (Pinus spp.). Pollen-influx data (not shown) show a similar pattern, with increased values for several taxa during the interval of reduced hemlock abundance. However, many coastal sites, where hemlock was rare, display a strikingly different dynamic. Oak, the dominant coastal taxon prior to $6000 \mathrm{cal}$. yr BP, declines by as much as $50 \%$ (Figs. 1 and 3), while beech, which changes slightly and variably at inland sites, increases $10-25 \%$ to reach its highest Holocene values ca. 5000 cal. yr BP. This pattern is most pronounced at sites on southwestern Cape Cod and the adjacent islands. A somewhat different change takes place at Owl Pond (Tzedakis 1992) and Wildwood Lake, Long Island, New York, where the decline in oak is associated with a minor change in beech and a major rise in pitch pine. Although hemlock pollen percentages are low at all coastal sites (Fig. 1) their abrupt decline at ca. 5500 cal. yr BP provides stratigraphic confirmation that the inland-hemlock and coastal-oak declines are exactly contemporaneous (Fig. 3). Hemlock values remain low at inland sites until ca. 4000 cal. yr BP, at which point they increase gradually until ca. 3000 cal. yr BP (Figs. 2 and 3). Similarly, at coastal sites a parallel increase in oak pollen percentages commences ca. 4000 cal. yr BP and continues through ca. 3000 cal. yr BP. Beech declines to a lower regional abundance by ca. $3000 \mathrm{cal}$. yr BP.

\section{Discussion}

This paleoecological evidence casts strong doubts on the interpretation of the hemlock decline in southern New England (USA) as caused solely by a pest or pathogen. The compositional changes at inland and coastal sites involved tree taxa that differ greatly in

hemlock and oak declines. Regression of North hemlock vs. Deep oak pollen percentage (average values for 400-year intervals between 8600 and $1800 \mathrm{cal}$. yr BP) yields $r^{2}=0.74$. (e) Hemlock pollen percentage for Wildwood Lake; values are relatively low overall, but the mid-Holocene decline is evident. (f) Pediastrum algae influx values for Wildwood; the high midHolocene values indicate a change in lake level and/or nutrient status during that interval. (g) Organic content (percentage losson-ignition, \% LOI) for Wildwood, featuring abrupt declines at ca. 8200 and 5500 cal. yr BP. Vertical shading highlights coincident changes in various proxies at ca. 8200 and ca. 5500 cal. yr BP. Triangles show data points used in the age-depth model for each site: open triangles are ${ }^{14} \mathrm{C}$ dates; solid triangles are age assignments based on pollen stratigraphy. 
physiology, morphology, pathology, ecology, and broad-scale distribution (Thompson et al. 1999), and yet the observed changes in these taxa were synchronous and equivalent in magnitude and rate (Fig. 3). We suggest that mid-Holocene climate change, rather than a biological agent, was the primary driver of both the hemlock decline in the inland region and the decline of oak and increase of beech at coastal sites. This finding adds considerable support to earlier suggestions regarding a link between climate and the hemlock decline (e.g., $\mathrm{Yu}$ and McAndrews 1994, Haas and McAndrews 2001, Calcote 2003, Shuman et al. 2004), but it does not exclude the possibility that pests or pathogens may have affected hemlock trees in response to their stressed condition or the altered climate setting (cf. Bhiry and Filion 1996, Haas and McAndrews 2001, Shuman et al. 2001, Calcote 2003).

\section{Regional evidence for dry climate during the middle Holocene}

Diverse paleoenvironmental evidence indicates that substantial mid-Holocene climate changes occurred in New England, elsewhere in northeastern North America, and possibly at the global scale. For example, waterlevel reconstructions in southeastern Massachusetts indicate that the interval of the hemlock and oak declines was characterized by extremely low moisture availability (Shuman et al. 2001). At Crooked Pond, lake levels dropped $2-3 \mathrm{~m}(\sim 4 \mathrm{~m}$ below present-day level) at ca. 5500 cal. yr BP and remained low until ca. 3000 cal. yr BP (Fig. 3), whereas sediments at Makepeace Cedar Swamp shifted from lacustrine mud to peat at ca. 5300 cal. yr BP (Newby et al. 2000). Likewise, increased abundance of Pediastrum algae from ca. 5000 to $3000 \mathrm{cal}$. yr BP in sediments from Wildwood Lake on Long Island (Fig. 3) suggests a region-wide change in water levels, perhaps accompanied by changes in nutrient status (e.g., Jankovska and Komarek 2000, Komarek and Jankovska 2001). Lake-level studies from other sites in northeastern North America reveal similar mid-Holocene changes (e.g., Lavoie and Richard 2000, Dieffenbacher-Krall and Nurse 2005, Shuman et al. 2005b). Meanwhile, analyses of sediment isotope geochemistry suggest that these dry conditions between ca. 6000 and 3000 cal. yr BP resulted from changes in largescale atmospheric circulation patterns (Yu et al. 1997, Kirby et al. 2002).

In addition to hemlock and oak, other taxa also exhibit changes indicative of warm, dry conditions during the middle Holocene. For example, hickory (Carya), a tree that prefers relatively warm conditions and reaches its present-day northern range limit in southern New England, increases at sites across the region at ca. 6000 cal. yr BP (e.g., Shuman et al. 2004). The pollen record from Hemlock Hollow, located near the Black Gum Swamp at the Harvard Forest in central Massachusetts (Fig. 1), features a decline in birch (Betula) between ca. 6000 and 3300 cal. yr BP, also indicating warm, dry climatic conditions (Foster and Zebryk 1993). This site also exhibits vegetational evidence for an increase in effective moisture coinciding with the post-decline increases in oak and hemlock at ca. 3300 cal. yr BP. The Hemlock Hollow record shows that spruce (Picea), a northern or montane taxon that occupies wetlands in southern New England, increased in abundance at that time. A coincident shift to cooler conditions is also indicated by a decrease in the maximum elevation of white pine and hemlock in the Adirondacks (New York) and White Mountains (New Hampshire) (Davis et al. 1980, Jackson and Whitehead 1991, Spear et al. 1994).

\section{Evidence for an abrupt climatic event at ca. 5500 cal. yr BP}

The long duration $(\sim 3000$ years) and large spatial extent of the mid-Holocene changes in forest composition in northeastern North America are consistent with orbital-scale variations in synoptic climatology (e.g., Shuman et al. 2005a). On the other hand, the abrupt onset of the hemlock and oak declines is somewhat enigmatic given our current understanding of Holocene climate history. Emerging evidence from high-resolution analyses of lake sediments from southern New England and elsewhere, however, suggests that these abrupt changes coincided with one or more intervals of intense drought. For example, at Wildwood Lake the drop in hemlock pollen percentages is coincident with a brief, but dramatic, decline in organic content (Fig. 3). Similarly, strong, century-scale droughts appear at 5800 and 5300 cal. yr BP at Shephard Lake, Ontario (Haas and McAndrews 2000), and the ostracode record from Elk Lake, Minnesota, USA, indicates prolonged low-water events at 5400 and 5200 cal. yr BP (Smith et al. 2002). In fact, major climatic shifts between 6000 and 5000 cal. yr BP, ascribed to changes in solar activity and/or oceanic circulation, have been observed in paleoenvironmental records from sites worldwide (Magny and Haas 2004, Magny et al. 2006). A decline in hemlock in response to sharply reduced moisture availability is consistent with its environmental tolerances, as hemlock has high moisture requirements relative to other common New England trees (Thompson et al. 1999, Shuman et al. 2004).

\section{Long-term parallels in coastal oak and inland hemlock}

Early-Holocene vegetation changes at sites in southern New England provide additional insights into the mid-Holocene environmental and ecological dynamics, as they demonstrate the striking similarities between the long-term records for coastal oak and inland hemlock (Fig. 3), confirming that these changes parallel regional and global climate. From ca. 10000 cal. yr BP onwards, oak pollen percentages at Deep Pond closely match those for hemlock at North Pond in overall trajectory and specific details. These details include an abrupt decline at ca. 8200 cal. yr BP, which various lines of 
evidence (Shuman et al. 2002, 2004, Alley and Ágústsdóttir 2005), including a drop in organic content in Wildwood Lake sediments (Fig. 3), identify as a brief, dramatic interval of cold and dry conditions. The similarity between variations in inland hemlock and coastal oak abundance throughout the Holocene and the clear relationship between those variations and both gradual, long-term and rapid, short-term climate changes present a compelling argument that the midHolocene decline in both species was driven by climate.

\section{Reevaluation of the relevance of the hemlock decline}

The close association between climate change and vegetation dynamics highlighted here strengthens the assertion of Webb (1986) and Shuman and colleagues (2004) that at many spatial scales forest dynamics are in equilibrium with regional climate. Notably, and contrary to many previous assertions, the mid-Holocene hemlock decline does not provide an example of ecological disequilibrium and should not be used as a model system for investigating ecological and evolutionary processes surrounding the selective removal of a single species (Davis 1981, Fuller 1998). Similarly, interpreted changes in lake productivity, water levels, and sediment characteristics coincident with the decline are likely more strongly tied to the direct effects of changes in temperature, precipitation, moisture balance, and hydrology than to the indirect consequences of forest-ecosystem dynamics and associated changes in evapotranspiration, biomass accumulation, and nutrient retention (Hall and Smol 1993, St. Jacques et al. 2000). Finally, if the hemlock decline was strongly driven by climate, it does not offer insights into recent and ongoing pest and pathogen outbreaks like the chestnut blight and the hemlock woolly adelgid, as has been asserted (Allison et al. 1986, Foster 2000).

Nonetheless, this climate-centric interpretation of mid-Holocene vegetation dynamics has great relevance to present-day ecological issues and understanding. First, this finding supports the contention that climate change may generate quite rapid and pronounced changes in regional forest composition (e.g., Ammann et al. 2000, Tinner and Lotter 2001, Williams et al. 2002). Although our stratigraphies are not tightly constrained chronologically, we record massive declines in hemlock and oak occurring over less than $\sim 500$ years. These results also present an opportunity to explore the range of adjustments in ecological, biophysical, and cultural systems under a major regional change in environment and vegetation. Consequently, this episode offers some interesting insights into systems like those in the modern world that are exposed to rapid environmental change. From this perspective our results underscore the extreme difficulty in sorting out the complex interactions among the environmental and biological systems that drive broad ecosystem dynamics, even in the absence of the additional complications interjected by substantial human activity.

\section{ACKNOWLEDGMENTS}

We thank Brian Hall for assistance with figures, Bryan Shuman for supplying the Crooked Pond data, and Aaron Ellison, Elizabeth Farnsworth, Janice Fuller, Steve Jackson, Jason McLachlan, Glenn Motzkin, John O'Keefe, Dave Orwig, Tom Webb, Herb Wright, Jean Nicolas Haas, and two anonymous reviewers for comments on the manuscript. Funding was provided by the National Science Foundation, the A. W. Mellon Foundation, and the National Ocean Sciences Accelerator Mass Spectrometry Facility.

\section{Literature Cited}

Alley, R. B., and A. M. Ágústsdóttir. 2005. The 8k event: cause and consequences of a major Holocene abrupt climate change. Quaternary Science Reviews 24:1123-1149.

Allison, T. D., R. E. Moeller, and M. B. Davis. 1986. Pollen in laminated sediments provides evidence for a mid-Holocene forest pathogen outbreak. Ecology 67:1101-1105.

Ammann, B., H. J. B. Birks, S. J. Brooks, U. Eicher, U. von Grafenstein, W. Hofmann, G. Lemdahl, J. Schwander, K. Tobolski, and L. Wick. 2000. Quantification of biotic responses to rapid climate changes around the Younger Dryas - a synthesis. Palaeogeography, Palaeoclimatology, Palaeoecology 159:313-347.

Anderson, P. K., A. A. Cunningham, N. G. Patel, F. J. Morales, P. R. Epstein, and P. Daszak. 2004. Emerging infectious diseases of plants: pathogen pollution, climate change, and agriculture drivers. Trends in Ecology and Evolution 19:536-544.

Anderson, R. S., R. B. Davis, N. G. Miller, and R. Stuckenrath. 1986. History of late- and post-glacial vegetation and disturbance around Upper South Branch Pond, northern Maine. Canadian Journal of Botany 64:1977-1986.

Bennett, K. D., and J. L. Fuller. 2002. Determining the age of the mid-Holocene Tsuga canadensis (hemlock) decline, eastern North America. The Holocene 12:421-429.

Bhiry, N., and L. Filion. 1996. Mid-Holocene hemlock decline in eastern North America linked with phytophagous insect activity. Quaternary Research 45:312-320.

Bronk Ramsey, C. 2001. Development of the radiocarbon calibration program OxCal. Radiocarbon 43:355-363.

Calcote, R. 2003. Mid-Holocene climate and the hemlock decline: the range limit of Tsuga canadensis in the western Great Lakes region, USA. The Holocene 13:215-224.

Davis, M. B. 1969. Climatic changes in southern Connecticut recorded by pollen deposition at Rogers Lake. Ecology 50: 409-422.

Davis, M. B. 1981. Outbreaks of forest pathogens in Quaternary history. Pages 216-227 in D. Bharadwaj, Vishnu-Mittre, and H. Maheshwari, editors. Proceedings of the Fourth International Palynological Conference. Volume 3. Birbal Sahni Institute of Paleobotany, Lucknow, India.

Davis, M. B. 1989. Retrospective studies. Pages 71-89 in G. E. Likens, editor. Long-term studies in ecology. Approaches and alternatives. Springer-Verlag, New York, New York, USA.

Davis, M. B., R. W. Spear, and L. C. K. Shane. 1980. Holocene climate of New England. Quaternary Research 14:240-250.

Deevey, E. S., Jr. 1939. Studies on Connecticut lake sediments. I. A postglacial climatic chronology for southern New England. American Journal of Science 237:691-724.

Dieffenbacher-Krall, A. C., and A. M. Nurse. 2005. Lateglacial and Holocene record of lake levels of Mathews Pond and Whitehead Lake, northern Maine, USA. Journal of Paleolimnology 34:283-310.

Dunwiddie, P. W. 1990. Postglacial vegetation history of coastal islands in southeastern New England. National Geographic Research 6:178-195.

Foster, D. R. 2000. Hemlock's future in the context of its history: an ecological perspective. Pages 1-4 in K. McManus, 
editor. Proceedings. Symposium on Sustainable Management of Hemlock Ecosystems in Eastern North America (Durham, New Hampshire, USA, 1999). USDA Forest Service General Technical Report NE-267.

Foster, D. R., and J. Aber. 2004. Forests in time. The environmental consequences of 1000 years of change. Yale University Press, New Haven, Connecticut, USA.

Foster, D. R., and T. M. Zebryk. 1993. Long-term vegetation dynamics and disturbance history of a Tsuga-dominated forest in New England. Ecology 74:982-998.

Fuller, J. L. 1998. Ecological impact of the mid-Holocene hemlock decline in southern Ontario, Canada. Ecology 79: 2337-2351.

Gaudreau, D. C. 1986. Late-Quaternary vegetational history of the Northeast: paleoecological implications of topographic patterns in pollen distributions. Dissertation. Yale University, New Haven, Connecticut, USA.

Haas, J. N., and J. H. McAndrews. 2000. The summer drought related hemlock (Tsuga canadensis) decline in Eastern North America 5700 to 5100 years ago. Pages $81-88$ in K. McManus, editor. Proceedings. Symposium on Sustainable Management of Hemlock Ecosystems in Eastern North America (Durham, New Hampshire, USA, 1999). USDA Forest Service General Technical Report NE-267.

Hall, R. I., and J. P. Smol. 1993. The influence of catchment size on lake trophic status during the hemlock decline and recovery (4800 to $3500 \mathrm{BP}$ ) in southern Ontario lakes. Hydrobiologia 269/270:371-390.

Jackson, S. T., and D. R. Whitehead. 1991. Holocene vegetation patterns in the Adirondack Mountains. Ecology 72:641-653.

Jankovska, V., and J. Komarek. 2000. Indicative value of Pediastrum and other coccal green algae in palaeoecology. Folia Geobotanica 35:59-82.

Kirby, M. E., H. T. Mullins, W. P. Patterson, and A. W. Burnett. 2002. Late glacial-Holocene atmospheric circulation and precipitation in the northeast United States inferred from modern calibrated stable oxygen and carbon isotopes. Geological Society of America Bulletin 114:1326-1340.

Komarek, J., and V. Jankovska. 2001. Review of the green algal genus Pediastrum: implications for pollen analytical research. Bibliotheca Phycologica 108:1-127.

Lavoie, M., and P. J. H. Richard. 2000. Postglacial water-level changes of a small lake in southern Quebec, Canada. The Holocene 10:621-634.

Magny, M., and J. N. Haas. 2004. A major widespread climatic change around $5300 \mathrm{cal}$. $\mathrm{yr} \mathrm{BP}$ at the time of the Alpine Iceman. Journal of Quaternary Science 19:423-430.

Magny, M., U. Leuzinger, S. Bortenschlager, and J. N. Haas. 2006. Tripartite climate reversal in Central Europe 56005300 years ago. Quaternary Research 65:3-19.

Newby, P. C., P. Killoran, M. Waldorf, B. Shuman, T. Webb III, and R. S. Webb. 2000. 14,000 years of sediment, vegetation, and water level changes at Makepeace Cedar Swamp, southeastern Massachusetts. Quaternary Research 53:352-368.

Oswald, W. W., E. K. Faison, D. R. Foster, E. D. Doughty, B. R. Hall, and B. C. S. Hansen. In press. Post-glacial changes in spatial patterns of vegetation across southern New England. Journal of Biogeography.

Shuman, B., P. Bartlein, N. Logar, P. Newby, and T. Webb III. 2002. Parallel climate and vegetation responses to the early Holocene collapse of the Laurentide Ice Sheet. Quaternary Science Reviews 21:1793-1805.

Shuman, B., P. J. Bartlein, and T. Webb III. 2005a. The magnitudes of millennial- and orbital-scale climatic change in eastern North America during the Late Quaternary. Quaternary Science Reviews 24:2194-2206.

Shuman, B., J. Bravo, J. Kaye, J. A. Lynch, P. Newby, and T. Webb III. 2001. Late-Quaternary water-level variations and vegetation history at Crooked Pond, southeastern Massachusetts. Quaternary Research 56:401-410.

Shuman, B., P. Newby, J. P. Donnelly, A. Tarbox, and T. Webb, III. 2005b. A record of late-Quaternary moisturebalance change and vegetation response from the White Mountains, New Hampshire. Annals of the Association of American Geographers 95:237-248.

Shuman, B., P. Newby, Y. Huang, and T. Webb, III. 2004. Evidence for the close climate control of New England vegetation history. Ecology 85:1297-1310.

Smith, A. J., J. J. Donovan, E. Ito, D. R. Engstrom, and V. A. Panek. 2002. Climate-driven hydrologic transients in lake sediment records: multiproxy record of mid-Holocene drought. Quaternary Science Reviews 21:625-646.

Spear, R. W., M. B. Davis, and L. C. K. Shane. 1994. Late Quaternary history of low- and mid-elevation vegetation in the White Mountains of New Hampshire. Ecological Monographs 64:85-109.

St. Jacques, J. M., M. S. V. Douglas, and J. H. McAndrews. 2000. Mid-Holocene hemlock decline and diatom communities in van Nostrand Lake, Ontario, Canada. Journal of Paleolimnology 23:385-397.

Stevens, A. 1996. The Paleoecology of Coastal Sand Plain Grasslands on Martha's Vineyard, Massachusetts. Dissertation. University of Massachusetts, Amherst, Massachusetts, USA.

Suter, S. M. 1985. Late-glacial and Holocene vegetation history in southeastern Massachusetts: a 14,000-year pollen record. Current Research in the Pleistocene 2:87-89.

Thompson, R. S., K. A. Anderson, and P. J. Bartlein. 1999. Atlas of the relations between climatic parameters and the distribution of important trees and shrubs in North America. Professional Paper 1650-A, B. U.S. Geological Survey, Denver, Colorado, USA.

Tinner, W., and A. F. Lotter. 2001. Central European vegetation response to abrupt climate change at $8.2 \mathrm{ka}$. Geology 29:551-554.

Tzedakis, P. C. 1992. Effects of soils on the Holocene history of forest communities, Cape Cod Massachusetts, U.S.A. Géographie physique et Quaternaire 46:113-124.

Webb, T., III. 1982. Temporal resolution in Holocene pollen data. Pages 569-571 in B. Mamet and M. J.. Copeland, editors. Proceedings. Third North American Paleontological Convention (Montreal, Quebec, Canada). Volume 2. (University of Montreal, Montreal, Quebec, Canada.

Webb, T., III 1986. Is vegetation in equilibrium with climate? How to interpret late-Quaternary pollen data. Vegetatio 67 : 75-91.

Whitehead, D. R. 1979. Late-glacial and postglacial vegetational history of the Berkshires, western Massachusetts. Quaternary Research 12:333-357.

Whitehead, D. R., and T. L. Crisman. 1978. Paleolimnological studies of small New England (U.S.A.) ponds. Part I. Lateglacial and postglacial trophic oscillations. Polskie Archiwum Hydrobiologii 25:471-481.

Williams, J. W., D. M. Post, L. C. Cwynar, A. F. Lotter, and A. J. Levesque. 2002. Rapid and widespread vegetation responses to past climate change in the North Atlantic region. Geology 30:971-974.

Winkler, M. G. 1985. A 12,000-year history of vegetation and climate for Cape Cod, Massachusetts. Quaternary Research 23:301-312.

Yu, Z., and J. H. McAndrews. 1994. Holocene water levels at Rice Lake, Ontario, Canada: Sediment, pollen, and plantmacrofossil evidence. The Holocene 4:141-152.

Yu, Z., J. H. McAndrews, and U. Eicher. 1997. Middle Holocene dry climate caused by change in atmospheric circulation patterns: evidence from lake levels and stable isotopes. Geology 25:251-254. 